\title{
The Inequality in Dividing Household Chores in Novels about Working Mothers
}

\author{
Maya Kurnia Dewi ${ }^{1}$, Mochamad Rizqi Adhi Pratama ${ }^{2}$ \\ [mayakurnia@unw.ac.id, rizqi.adhi@unw.ac.id\} \\ English Literature Department, Universitas Ngudi Waluyo ${ }^{1}$, English Literature Department, \\ Universitas Ngudi Waluyo ${ }^{2}$
}

\begin{abstract}
In many countries, the rate of women's participation in the working field keeps increasing from time to time because of the increase in their educational level and economic condition. This condition leads to some changes concerning the gender roles in a family, however, it does not really change the division of household chores between husband and wife. Women are still considered as the main person to do most of the household chores. This topic is often presented as the main theme in some literary works, particularly novels. This research examines four different novels, Opening Belle, I Don't Know How She Does It, Kim Jiyoung Born 1982 and The Balance Project, by analyzing the inequality in dividing household chores faced by the working mothers in the novels. This research uses qualitative method consisting of description, reduction and selection stages. From the analysis results, it can be seen that the working mothers still do most of the household chores, while their husband does not help them much. Although they can pay someone to help them do the chores, however, the help is not as good as expected. They still have to struggle in combining between household chores and work which eventually makes them feel exhausted. Until now, it seems impossible for working women to balance between family and work because women's main roles are still to be at home.
\end{abstract}

Keywords: household chores, inequality, working mother, novels

\section{Introduction}

The increase of the number of women in the workforce is an important indicator of economic growth. The record of a sharp increase in the female workforce occurred in the 20th century where the number of women participating in the labor market in the early industrialized countries is shown in graph 1.0. This graph illustrates the level of participation of women who are economically active by combining data from countries that are members of the OECD (Organization for Economic Cooperation and Development). The chart shows a positive trend in all countries, although it starts at different points in time, and continues at different levels; however, substantial and sustained increases in female labor force participation in rich countries remain a striking feature of economic and social change in the 20th century. 


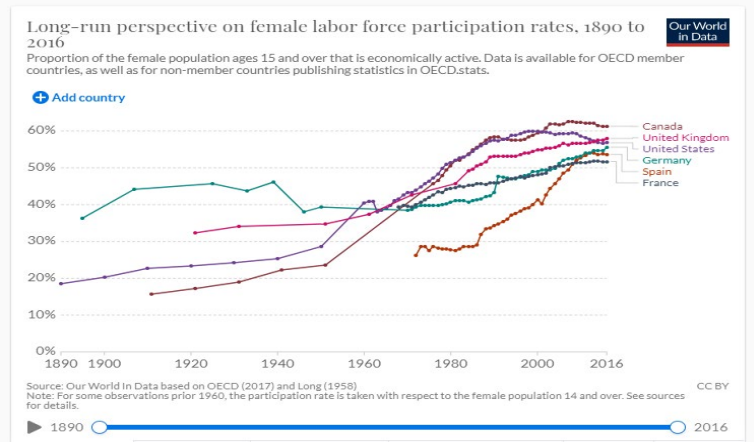

Fig 1. Long-term perspective of the participation of women in the workforce from 1890 to 2016. (https://ourworldindata.org/female-labor-supply)

In many countries, women's participation in the workforce increases along with the increase of economic growth and educational levels. It is important for women to have the opportunity to work because work can help overcome gender disparities such as in terms of income and decision making at work. This increase in the number of working women has changed some of the social treatments for women, but has not completely changed the roles of women at home. Women who work outside the home usually still have to play the role in taking care of their home and family. Their husband may contribute to taking out the trash or tidying the yard, but on average, they spend less time doing this than women do for other household chores. This applies to women who work full time or part time, even though they can pay someone to help out at home. In fact, if a woman can pay for help, in the end she also has to arrange how these workers clean the house or look after their children. She also still has to meet the needs of her children including being involved in school activities. From a survey conducted by the US Bureau of Labor Statitistics in 2015, women spent twice as much time on average per day to prepare food and drinks and clean the house, and three times as much on washing clothes than men. Meanwhile, men spent twice as much time in activities related to lawn, gardening, and repairs in and outside the home than women. Basically, women spend more time on doing household chores. This is shown in the following graph.

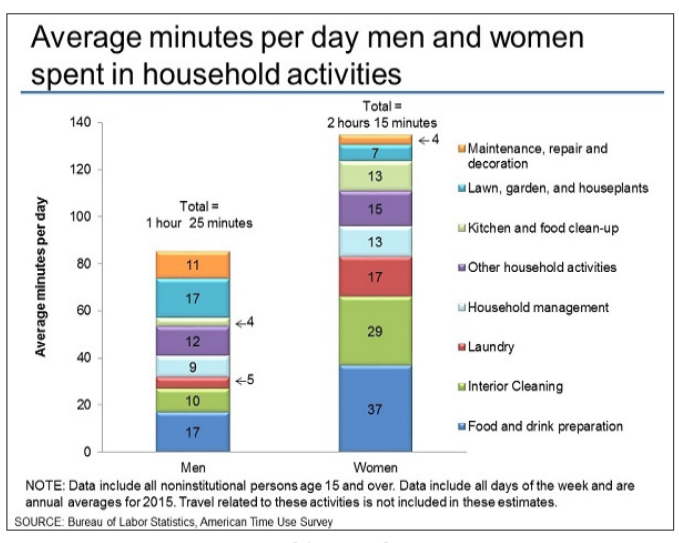

Fig 2. The comparison of average time per day (in minutes) for men and women doing household chores in America (https://www.bls.gov/tus/charts/household.htm) 
Gender inequality in domestic works has been a useful source of study in psychology as well as literature. Psychological studies describe real life that involves real investigation. Psychological effects have been studied a lot, especially with regard to Work-Family Conflict (WFC) or work-family conflict today [1]; [2]; [3]; [4]; [5]; [6].

Everyone, especially women who work, has a high tendency to experience conflicts between office and home work due to limited time and high levels of stress [7]. In psychological literature, there is a tradition in the study of office and home work [8]; [9]; [10]; [11]; [12]. [13] investigated gender inequality in domestic work related to the increase in Work-Family Conflict (WFC). The results show that traditional gender roles still influence the way men and women manage work and family interactions.

Syamsudin examines feminism in American society. The time setting was in the industrial era at the end of the 19th century [14]. The main source or data was the Main Street novel written by Siclair Lewis. The study reveals that by the end of the century, American women experienced discrimination and subordination. This novel promotes equality between men and women in social life. Another leading researcher, Van Hooff investigated the explanations and justifications offered by multiple career heterosexual couples in maintaining an unequal division of domestic work in their relationships [15]. The research findings reveal that a number of couples apply the same justification, with male and female respondents arguing that women have higher standards and are more competent in doing domestic work and that the definition of labor is practical, based on the hours worked on both partners.

Based on some of the studies above, there is still an imbalance in domestic work between men and women. This phenomenon triggers researchers to investigate this understanding by focusing on several literary works in novel form. Novels can represent various things, including the author's views about real life. Household chores consist of domestic duties, child rearing and kin work. The disparity in the division of household chores between a working mother and her partner is due to the patriarchal notion that defines household work as a woman's duty. This makes working women have to play double roles, namely at home and at work, and they must be able to balance these two roles well. The theme of the inequality of the division of household chores is raised in various literary works, especially novels, so this research will discuss the conflict of inequality in the division of household chores in four novels with the theme of working mothers, namely Opening Belle, I Don't Know How She Does It, Kim Jiyoung Born 1982 and The Balance Project.

\section{Methodology}

This study employs a qualitative research method consisting of the description, reduction and selection stages. The research stage begins by observing the depiction of the characters and the problems raised in the novel, continues to reduce the information obtained from the description stage and focuses on the problems raised in the theme, then ends by connecting the data obtained with the theory used. 


\section{Finding and Discussion}

Women's participation in the labor market has changed a lot in the last 50 years due to many factors such as the absence of additional salaries, the husband's single income is no longer able to meet the family needs, the growth of women's desire to enter public life and to gain economic independence, and the availability of childcare services [15]. The involvement of women in economic matters encourages changes in traditional gender roles. Stereotypes of women who should play a lot of roles in household chores now have to divide their roles with tasks in the workplace so they are prone to conflict. Therefore, she needs help from those around her so that she can carry out both roles well. Seccombe and Warner divide household chores into three interrelated series of activities, namely domestic tasks, child rearing and kin work [16]. This study will discuss inequality in the division of household chores by discussing four novels with the theme of working mothers, namely I Don't Know How She Does It by Allison Pearson, Opening Belle by Maureen Sherry, Kim Ji-yeong Born in 1928 by Cho Nam-Joo and The Balance Project by Susie Orman Schnall

As mentioned above, several factors cause women to participate in earning a living. In fact, sometimes they are forced to become the main breadwinner in their household or called as breadwinners. Maureen Sherry in her novel Opening Belle quotes a New York Times article that wrote that ... 40 percent of American households with children now have women being the primary breadwinner ... [17]. This condition is experienced by the main character in this novel named Isabelle McElroy. This is not much different from Katherine's character in the novel $I$ Don't Know How She Does It. The husbands of these two figures have temporary jobs so they still have to fulfill their family needs. However, their increased participation in work does not change the traditional gender roles adopted by patriarchalism.

Patriarchy refers to the dominance of men over power relations where men dominate women, as well as to define a system in which women are always placed lower in various ways [18]. Milllet adds that this male domination is carried out through various institutions such as high schools, churches and families, each of which justifies and strengthens the position of men over women [19]. Novel Kim Jiyoung Born 1982 mentions many forms of patriarchy adopted by the Korean people and passed down to subsequent generations. When Kim Jiyoung's mother was a teenager, she was required to work to help pay for her younger brother's school because it was the boy who was expected to be the successful person in the family ... boys are the core of family success and happiness [20]. In Kim Jiyoung's family, her grandmother treats her younger brother as special like not giving her the task of helping her mother do household chores and get the best food at home. The birth of Kim Jiyoung and her older sister was also not considered lucky in the family because they were expecting a son. So when Ji-yeong's mother was declared pregnant with her third child, when the doctor said that her child was thought to be a girl, Jiyoung's mother decided to abort it because her family implicitly would not accept if the girl was born. This situation made sex examination and abortion of girls' fetuses happen widespread. As a result, in the 1980s there was an imbalance in the gender ratio that peaked in the early 1990s, when twice as many boys became the third child in the family than there were girls.

Kim Jiyoung herself feels depressed when she is at a family gathering where family members share that they feel restless after giving birth to a daughter. They will feel proud in front of their in-laws when they are pregnant with a son and they will be able to eat expensive food when they are pregnant with a boy.

Domestic roles attached to women often place women working in a conflict because on the one hand, she has to be fully responsible for domestic tasks, while on the other hand she has 
responsibilities outside her home, namely work. Significant differences in the distribution of domestic work continue when the wife works outside the home. Winqvist's [21] research shows that women in Europe spend between 60 and 70 percent of their time doing household chores, while men spend 35 to 45 percent. This condition is almost the same as what happened in America as when the character Katherine In the novel The Balance Project, who works as a writer, is interviewed by one of the journalists who asks why the balance between work and household duties is still a hot issue. Kate said, "Well, women make up approximately 60 percent of the American workforce, yet they spend twice as many hours as men on childcare and housework." [22].

Domestication is part of feminine mystique which is described by feminist figure Betty Friedan in her book entitled Feminine Mystique. In this book she defines what is currently referred to as the stereotype of ideal women as those who find feminine fulfillment when she focuses only on her husband, her children and her home [23]. The novel I Don't Know How She Does It shows the existence of domestication through religion when Kate opened a book entitled Saying of the World's Great Religion which says that the wife is 'home' thus affirming the notion of domestication of women. This causes Kate to feel guilty because she does not stay home often to take care of the house and her family. Patriarchy causes Kate's husband not to feel the way Kate feels when he has to work outside the home because this understanding says that the role of men is in the public sphere ... no man has ever had to ask for advice on how to combine fatherhood and a career [24]. The privilege of this men's roles causes them not to be much involved in activities related to household duties, so that if they are involved, they feel proud and can show it off to those around them. Both Opening Belle and I Don't Know How She Does It show readers how fathers display photos of their children on their desks to show that they can still make time for them in the midst of busy life. Belle character says, "Men have no problem. impressing their bosses with their family-man rap; while women never dare mention their families at work, "[25]. In line with this, the character Kate said that if a man puts up a photo of his child on the table, it shows that he is a good head of the family, while if this is done by a woman, the impression will be the opposite. This is because the nature of men is not being in his house with his children; it is women who have this responsibility.

\subsection{The Inequality in Dividing Household Chores in Novel I Don't Know How She Does It}

The novel I Don't Know How She Does It tells about the character of Katherine or often called Kate, a successful career woman who works at a leading financial company, Edwin Morgan Forster, as the youngest senior director. He is 35 years old and has two children, Emily and Ben. Her husband, Richard, works for a housing agency where the job is only temporary. In accordance with the title of this novel, Kate's daily life is full of considerations about who needs her attention the most; whether children, job or husband. Although Richard stays at home more often because he does not always have to go to work, Kate still has to do various household chores. The task of cooking, for example, is still Kate's responsibility even though at that time she comes home late from work. She is forced to do it because she reads a letter from Emily's school asking Emily to bring snacks in Christmas party at school. Kate concludes that every letter from school addressed to parents is meant to be addressed to the mother ... (Has a father who has a wife on the premises ever read a note from school?) [24]. Kate is willing to do this because she remembers when she was a child, her friend who brought food from the shop at the Harvest Festival at the church was thought to have a mother who did not pay attention to her 
child because she was busy working. Kate does not want Emily to get the same treatment that can cause Emily to feel sad and then has a psychological impact until Emily adult.

Apart from cooking, the household chore that Kate has to do is cleaning the house which she does after she finishes cooking snacks for Emily. She sees that the kitchen is in a mess; toys are scattered all over the place, a pile of raisins that has been there since morning, rotten fruit that is still on the dining table, as well as dirty napkins that no one other than herself will think of throwing away. Richard, her husband, asks her to rest because it has been so late at night, but Kate cannot do it. Richard does not help Kate much with cleaning the house. Kate repeatedly reminds Richard to clean the house but Richard often ignores Kate's requests

11.19 P.M. Arrive home to discover the Pocket Memory Connect Kit on the hall table. Richard is shipwrecked on the sofa watching the Arsenal Game. He has left some pasta in the oven; it has the texture and smell of baked toes.

"Would it be totally out of question for anyone except me to take stuff left at the bottom of the stairs upstairs?" [24]

The task of cleaning the house as if it is a woman's destiny is depicted in Kate's mother character, who never seats as long as Kate's memory. She always stands in the sink, irons the clothes, carries the dishes of food from the kitchen and after that takes them all back. Her mother's generation was born to provide services for the family so that she will lose direction if this was taken from her. When Kate was a teenager, she thought that even though in fact men seemed to play an important role in the world, it was actually women who made men able to appear in public well ... It was a matriarchy pretending to be a patriarchy to keep the lads happy [24]. This view is also shared by Kate's mother-in-law, Barbara. In Barbara's life, husbands are not involved in household chores at all. Barbara treats her husband like a farm animal that needs special care, so she will blame Kate if Richard looks thin. To ease the responsibilities of doing domestic chores, Kate hires Juanita to clean her house. But the help she expects from Juanita is difficult to fulfill because Juanita often complains about pain in various parts of her body, so she is unable to clean the house thoroughly. As a result, Kate still has to do domestic tasks after working or on holidays. Shopping is also part of Kate's job because Richard is often embarrassed if he is asked to buy household supplies that are identical to women. He tells Kate that he refuses to be asked to buy things like toilet paper, sanitary napkins or air freshener.

Apart from domestic tasks, an inequality in the division of household chores is also evident in terms of child rearing. To help her take care of her children while she is working, Kate hires a nanny named Paula who is often late to come to Kate's home. Kate can go to work only when Paula has arrived, while Richard can leave without thinking about it. Paula's late arrival also results in Kate being late to the office. In order not to be judged badly by his superiors, she has to give reasons for being late on what are called as male reasons, such as traffic jams on the road. If she gives the reason for the delay because she has to take care of her children first, she will be considered as an employee who does not put the interests of the company first. But on the other hand, society still demands a mother as the party who is most responsible for ensuring the welfare of the child. Paula is the person Kate really counts on when she is not at home. Problems will arise when Paula cannot come to Kate's house because she is sick. This situation causes Kate to find a way out before she can go to work, while Richard has left home. Kate, who is scheduled to chair an important meeting that day, decides to leave Ben and Emily with her neighbors for a while. In addition, a mother is also required to be able to deal with her sick child. Ten-month old Ben is in a teething period which makes him cry a lot at night. A tired Kate awakes immediately when she hears Ben's screams, while Richard is still fast asleep. To 
ease the pain, Ben accidentally bites Kate's neck leaving a red mark on Kate's neck. Kate's friend asks her about the mark.

"Hey, did Slow Richard give you a hickey? That's terrific honey. "

"No, the teething baby did. My darling husband slept through all. But I nearly bit him to wake him up [24]

Child welfare also involves parents' participation in the school activities. Emily's friends' parents expect Kate to attend a meeting between parents and teachers held before Kate comes home from work. As a result, three months after joining, Kate never attends a single meeting. Since the beginning, Kate's goal in joining this organization is to take part in Emily's education like the mothers of Emily's friends who mostly are housewives. ... I was thinking that just for one hour in some underlit overheated classroom, I could pretend that I'm like any other mother [24]. Alexandra Law, the head of this organization, often insinuates that Kate is still working full time so that she does not have much role in school activities. Another activity at Emily's school that Kate wants to attend is a Christmas play that she can barely attend because she has a sudden assignment from her boss. She finally arrives late which is indicated by the sound of his shoes on Emily's school floor which seems to be made to expose a working mother who is late to come. Kate is eager to attend the show because last year she could not attend it because she had to catch a flight to America. The times she cannot come are the times the kids will remember, not the other way around.

The third type of household chores is duties towards relatives or often called as kin work. In the midst of her busy schedule, Kate still has to think about the Christmas gifts she should bring to celebrate at her mother-in-law's house. The process of giving gifts, starting from buying wrapping paper, buying gifts, giving words in it until sending it through the post office is entirely done by Kate.... One tradition is that I buy all the presents for my side of the family [] and presents for Richard's parents .... [24]. But when they are at Richard's parents' house, Richard's father and mother would rather thank Richard for bringing them gifts and wine. Kate feels disrespected for her efforts.

To make up for her guilt because she cannot involve a lot in her child's development, Kate buys various items to please her children. Currently Emily has a variety of toys that marks Kate's guilt. Kate's guilt arises even when Emily wasn't born. Kate was the first woman to become pregnant in Edwin Morgan Forster's investment department. When she was six months pregnant, she was summoned by her boss who was not sure to keep Kate's job once Kate returned from maternity leave. This company actually has a friendly policy towards married employees, but because policies such as maternity leave has never been used by men, women should also not use them so that they do not want to be considered to be not serious about working. As a result Kate tried to work harder so as not to lose her job. Entering 32 weeks of pregnancy Kate was told by her obstetrician that Kate was too stressed to endanger her baby's brain development. Kate's guilt led her to choose to give birth normally without the aid of an epidural so she could prove to her baby that there was still something she was willing to bear for her child.

To balance roles at home and at work, a working mother must be able to do many things at one time or called as multitasking. Kate tells her husband that she should be able to remember everything, while it will be impossible to ask Rich to remember three things at the same time. In addition, a working mother must also be seen to be able to separate the two roles. When she is at home she must act as a mother, while when she is at the office, she must act as a good employee. 
This conflict of inequalities in the division of household chores makes Kate exhausted. She continues to feel guilty because she often leaves her growing children who need her so much. She finally choses to sacrifice his job to be with his family. In the case of conflicts related to home and work, the wife is usually the party who has to give in to stop working because the main breadwinner is supposed to be her husband. This kind of conflict is also faced by another working mother figure named Jill Cooper-Clark. Jill Cooper-Clark, is the wife of Kate's boss in the novel I Don't Know How She Does It. Jill originally had a good career at the Ministry of the Domestic Matters until Sam, her second child, was two years old. She should have got a high position now, but she finally decided to take care of her family. According to her, she and her husband, Robin, cannot both have full-time jobs without leaving an impact on the development of their children. When faced with things like this, usually the wife who is forced to choose to stop working because she is the main party responsible for matters related to the family. This is different from men who socially and patriarchically do not choose between work and family because their main position is in the public sphere while women are in the domestic sphere.

Even the novel I Don't Know How She Does It presents several chapters that discuss court for working mothers. This court is in charge of judging the working mother, in this case Kate, if she does not know the things that happen at home. For example, when Kate tells her motherin-law that Emily likes broccoli when in fact she does not. The judge in this court charges Kate guilty because this thing should have been known by a mother despite the fact that a child's tastes are always changing. Kate feels this accusation is unfair because Richard does not know this either but he is not charged guilty

.... well, there's no way that Richard would know whether Emily liked broccoli or not, but him not knowing seems normal. The mother not knowing, it feels unnatural ... "[24].

\subsection{The Inequality in Dividing Household Chores in Novel Opening Belle}

The second novel to be discussed in this study is entitled Opening Belle by Maureen Sherry. The main character in this novel is a working mother named Isabelle McElroy in her 30s. He is married to Bruce Cassidy and has three children. Isabelle or Belle works as an executive manager at a stock company called Feagin Dixon located on the Wall Street complex. Belle's husband, Bruce, does not have a steady job and is at home more often than Belle. One of Belle's domestic tasks is shopping for her family's daily needs. Her husband, Bruce, does not care if the refrigerator is empty so Belle has to be responsible for buying groceries. Having three young children means that Isabelle and Bruce's house never looks clean. Isabelle's full-time job keeps her from tidying up her house so she hires a household assistant to help her. But the housekeeper has often already come home when the house is still messy and Bruce does not want to clean it up. They tend to let the condition because they get used to it and Belle will take care of it in the end. One day Kate is angry about this and says

"It says nobody cares at all. It says let all this shit hang out till Mom comes home because she'll fix everything. She'll earn the money! She'll order all the groceries and arrange for cleaning and cooking ... "[25].

Meanwhile, in terms of child rearing, Belle also plays a more dominant role than her husband, even though her husband is more often with them. Belle's friend said, "I think you're still doing most of the kid work even though he's home most of the time." [25]. Even though Belle often has to make official trips abroad for her work, she still has to make many arrangements for her home and family members so that all activities can run well, for example whether Kevin, the eldest son, has been picked up after playing with his friends; what her 
household assistant cooks for dinner and whether Owen, her youngest son, can take a good nap. Belle is also responsible for choosing the clothes the children will wear tomorrow because when this responsibility is given to Bruce, he could not choose an appropriate outfit, such as when Belle was told by Brigid's teacher that Brigid went to school without wearing underwear. Belle often covers up the condition of her family by saying that Bruce plays a lot in taking care of the children so that her husband will not to be blamed for not working. "Bruce helps a lot with the kids." I lied [25]. When in fact what Bruce does more often is to have fun with the money that Belle is making. Bruce is too lazy to find work because he could rely on his wife's income. Bruce's immaturity is also seen when Belle has a meeting with other working mothers with toddlers. Belle decides to join this play group meeting because she wants to be more involved in her children's activities. Belle is almost late because she suddenly gets an additional assignment from her boss. When she gets home she finds hers babysitter angry because she has to watch over all the toddlers who are there, while Bruce is busily drinking wine with Belle's guests.

Like Kate, the responsibility towards relatives is also Belle's, for example when she has to buy Christmas gifts for her family. Belle buys these gifts before she attends the office party before the Christmas holidays. Belle feels embarrassed to bring this bag of toys to a party in her office because everyone looks elegant without carrying a big bag of toys like her. This bag makes her look so motherly that she wants to hide behind her friend, Marcus. Hide me Marcus. I look like a mother, for God's sake ... [25]. The toy bought by Belle sounds many times when Belle accidentally stumbles on something. This attracts the attention of her friends who are motivated to play it until one of his children's toys is broken.

Being busy makes Belle feel guilty for leaving her children too often. She feels that she loses a lot of time with them. Time passed makes Belle realize that now her children are getting bigger. In fact, the time given to parents to raise their children is not as long as one might think because they are growing rapidly. Most things are not there for us as long as we think that they will be [25]. But for now, Belle can not decide to stop working because her family still needs income from her. Although for Belle's friends, combining a work life with a family of three children is not possible.

However, this conflict makes Belle exhausted. Her workmates often doubt her ability to get the job done because she has too many things to handle. She feels able to handle everything even though she also feels that she has too much responsibility. I'm fully capable of taking care of Bruce and our brood; it's just so much responsibility. It's so lonely [25]. Belle also has to find a way to keep household and work separate. Belle calles this separation the mental filing cabinet. Each piece is placed in a different container and ensured that no leaks occur. This is often difficult, but not impossible.

"She jams a family problem into a mental filing cabinet, slams the door shut, and does her work. When she gets home she reverses the process, disconnecting her wireless world while reviewing first-grade spelling words .. "[25]

Bruce's immaturity finally makes Belle feel unable to maintain the household chores. She decides to divorce from Bruce and then quits from the previous company to set up her own business. By having her own business, Belle hopes that she will be able to better manage her working hours so that she can still have time with her children.

\subsection{The Inequality in Dividing Household Chores in Novel Kim Ji Young Born 1982}

The novel Kim Ji Young born 1982 features several working female figures including the mother of Kim Ji Young and Kim Jo Young herself. Ji Young's mother is a housewife who 
works part time to help with household finances. Some of the works that Ji Young's mother did included wrapping clothes, folding boxes, gluing envelopes, peeling garlic, rolling up window screens and so on. She did not go to the office every day like her husband who was a civil servant, but she did this job in addition to completing all household chores ... while doing chores all on her own and looking after three children and an elderly mother- in-law [26]. Of all these side jobs, the heaviest job was rolling the window divider because the glue used would stick tightly and often injure if pulled too hard. Gradually, Kim Ji Young's mother's work grew and the time she spent working was getting longer. One day Kim Ji Young's father came home after working late and still saw his children helping their mother roll up the insulation. He rebuked his wife for still letting her child work late at night. Feeling guilty after this incident, Kim Ji Young's mother decided to stop all side jobs.

Not only Kim Ji Young's mother who is required to be responsible for household chores. Ji Young's paternal grandmother, Go Sun-bun, even had to take care of all her family needs because her husband never wanted to take care of his family. But Go Sun-bun fully accepted her husband's situation. She really thought that her husband was a good man because of him not having an affair and not committing domestic violence against her.

As for the character Kim Ji Young herself, patriarchy has been instilled since she was a child because she and her older sister were assigned to help his mother wash dishes or clean the house, while her younger brother was not assigned any tasks. The similar task continues until she has got a child. She has about three hours to do household chores to wash clothes and dirty dishes that pile up, clean the house and cook for the baby while she leaves the child at day care. Many people think that housewives who leave their children at the daycare can rest in peace. In fact, she still has to do household chores during her spare time.

In terms of child rearing, it is also the responsibility of a mother. Ji Young's mother said that when she was little, Ji Young's sister cried a lot so she often took her to the hospital many times. Even after Ji Young and his younger brother were born, his father never helped take care of their children .... I had three, your father never changed a single diaper .. [26]. Another character of working woman in this novel is the doctor of Ji Young who also experiences inequalities in parenting. At first she and her husband thought that their child's mental condition was fine even though they both had to work. One day his son's teacher told them that their son hurt his friend's hand and did bad things at school. The homeroom teacher of his child suggested that for the time being the child should be under the supervision of his mother so that his behavior would improve. The child's mother finally took a temporary leave of absence, but when his son's condition did not improve, she was forced to stop working.

In terms of having a relationship with relatives, Kim Ji Young is required to be present at her in-laws house to celebrate Chuseok with her husband's family. There she will help his mother-in-law buy materials food at the market and then cook before other family members arrive.

Before getting married, Ji Young works for a large company with about fifty employees. Ji Young enjoys her job here because even though the company has many shortcomings and the salary is not satisfactory, the company has become a place where she is free to be herself. At first Ji Young is still working when she knows that she is pregnant and her company allows pregnant female employees to arrive thirty minutes later to ensure her safety. But when Ji-yeong announces her pregnancy to her co-workers, the male workers are jealous of this rule. Kim Ji Young feels annoyed with them because they only see things that benefit Ji-yeong without seeing the discomfort a pregnant woman.

Actually Ji Young wants to keep working after giving birth, but when she realizes that there is no one to ask for help to take care of her child, she is forced to stop working ... In the end, 
they concluded that one of them had to be a stay-at -home parent, and that person, of course, was Ji-young [26]. The decision is taken by considering that at that time her husband's job is more stable and, moreover, in accordance with the general assumption that the husband should work while the wife raises the children and manages the house.

When her husband says he will help Ji Young do household chores, Ji Young feels annoyed because she feels that her husband just wants to help her, while in fact, he also has the main responsibilities in the home. She also feels that a working mother who decides to quit because she has to look after her child will lose a lot of things including youth, health, work, colleagues, friends, life plans and the future. Meanwhile, a husband will not lose much when he has children. When a mother wants to return to work after giving birth, it will be difficult for her to find a decent job. Available jobs include freelance workers, private tutors, cashiers, restaurant waiters or other jobs that can be done part time because she still has to take care of her children.

\subsection{The Inequality in Dividing Household Chores in Novel The Balance Project}

The novel The Balance Project is actually more about Lucy Cooper, a well-known assistant writer, Katherine Whitney, who wrote a book "The Balance Project" which tells about how working women need to balance roles at home and at work. In her book Katherine says that a woman can succeed in her career, and domestic life. This is because Kate has an assistant at work, her children are still young and she can pay for domestic helpers and nannies. Her husband, Theo, is also very supportive of her career. Kate says that although she does not spend much time with her children, they are always together on weekends as a family. She feels there are no problems in her household and her children look happy. But when the babysitter of her children complains of being sick almost every day while she has to take care of her business, she starts to feel overwhelmed and she feels that her life is now a mess. "...... I'm a mess. I don't know how I possibly thought I could manage all of this. It's too much. " [22]. The impossibility of balancing career and domestic life is also expressed by another character in this novel, named Dr. Elaine Ireland who says:

.... This idea of being superwoman. That you can do everything-taking care of your career, your children, your marriage, and yourself-all really well and that everyone in that equation-your boss, your family, you-will be happy and sane and well all the time. But in reality, that's impossible ....." "[22].

Contrary to her work, which reveals the possibility of balancing domestic life and work, in reality Kate is incapable of doing it. She finally decides to concentrate on her family and quits working.

\section{Conclusion}

From the analysis of the discussion on the theme of the inequality in dividing household chores from the four novels with the theme of working mothers, it can be seen that both working mothers who work full time like the two characters Kate and those who work part-time like Kim Ji Young's mother experience an inequality in the division of household chores which includes domestic tasks, child care and kin work. This inequality in the division of household chores is due to the patriarchal notion that places women in the domestic sphere and men in the public 
sphere. When women decide to enter the public domain, their responsibilities in the domestic sphere have not changed much. They are still the main party in charge of the domestic sphere. If they are unable to fully handle household tasks, they should find someone who can help them. The two characters Kate finally decide to stop working because they have difficulty handling the two roles simultaneously. Meanwhile, Belle and Kim Ji Young's mother decide to open their own business so that they can handle the two domains more freely. Until now, the balance between work and household affairs for working mothers is still difficult to achieve because of the patriarchal understanding that is still widely embraced by the community.

\section{Acknowledgments}

Thank you to the Ministry of Research, Technology and Higher Education 2019 for the TA Beginner Lecturer Research Grant (PDP). 2020.

\section{References}

[1] Eby LT, Casper WJ, Lockwood A, Bordeaux C, Brinley A. Work and family research in IO/OB: Content analysis and review of the literature (1980-2002). Journal of vocational behavior. 2005 Feb 1;66(1):124-97.

[2] Ammons, S. K., and Kelly, E. L., eds. Work and Family in the New Economy. Research in the Sociology of Work, Vol. 26. 2015. Bingley: Emerald Group Publishing Limited.

[3] French KA, Dumani S, Allen TD, Shockley KM. A meta-analysis of work-family conflict and social support. Psychological bulletin. 2018 Mar;144 (3):284.

[4] Lapierre, L. M., Li, Y., Kwang, H. K., Greenhaus, J. H., Di Renzo, M. S., and Shao, P. A metaanalysis of the antecedents of work-family enrichment. J. Organ. Behav. 2017. 39, 385-401.

[5] Wayne JH, Butts MM, Casper WJ, Allen TD. In search of balance: A conceptual and empirical integration of multiple meanings of work-family balance. Personnel Psychology. 2017 Feb;70(1):167-210.

[6] Carvalho VS, Chambel MJ, Neto M, Lopes S. Does Work-Family Conflict Mediate the Associations of Job Characteristics With Employees' Mental Health Among Men and Women?. Frontiers in psychology. 2018 Jun 13;9:966.

[7] Greenhaus JH, Beutell NJ. Sources of conflict between work and family roles. Academy of management review. 1985 Jan 1;10(1):76-88.

[8] Kopelman RE, Greenhaus JH, Connolly TF. A model of work, family, and interrole conflict: A construct validation study. Organizational behavior and human performance. 1983 Oct 1;32(2):198215.

[9] Edwards JR, Rothbard NP. Mechanisms linking work and family: Clarifying the relationship between work and family constructs. Academy of management review. 2000 Jan 1;25(1):178-99.

[10] Pitt-Catsouphes M, Kossek EE, Sweet S, editors. The work and family handbook: Multi-disciplinary perspectives and approaches. Routledge; 2015 Nov 30.

[11] Mills MJ. Gender and the work-family experience. New York, Springer; 2015.

[12] Paulin M, Lachance-Grzela M, McGee S. Bringing work home or bringing family to work: Personal and relational consequences for working parents. Journal of Family and Economic Issues. 2017 Dec 1;38(4):463-76.

[13] Cerrato J, Cifre E. Gender inequality in household chores and work-family conflict. Frontiers in psychology. 2018 Aug 3;9:1330.

[14] Syamsuddin S. FEMINISM IN SINCLAIR LEWIS'MAIN STREET. LiNGUA: Jurnal Ilmu Bahasa dan Sastra. 2007;2(2).

[15] Dex S. Work and Family in the Twenty-First Century. York, UK: Joseph Rowntree Foundation. 2003. 
[16] Seccombe K, Warner RL. Marriages and families: Relationships in social context. Wadsworth Publishing Company; 2003.

[17] Sherry M. Opening Belle: A Novel. Simon and Schuster; 2016 Feb 2.

[18] Bhasin K. What Is Patriarchy Women. Unlimited, New Delhi. 2006.

[19] Millett K. Sexual Politics (London, Virago). THE'DECLINING SIGNIFICANCE'OF PATRIARCHY. 1977;33.

[20] Stokols D. Social ecology in the digital age: Solving complex problems in a globalized world. Academic Press; 2018 Jan 2.

[21] Winqvist K. How Europeans spend their time. Everyday life of women and men. Rapport de la Commission Européenne, Luxembourg: Pocketbooks Edition. 2004.

[22] Schnall, S. O. The Balance Project. Arizona: SparkPress. 2015.

[23] Friedan B. The feminine mystique. WW Norton \& Company; 2010 Mar 1.

[24] Pearson, A. I Don't Know How She Does It. New York: Anchor Books.2002.

[25] Sherry M. Opening Belle: A Novel. Simon and Schuster; 2016 Feb 2.

[26] Cho, N. J. Chang, Jamie. Kim Ji Young Born 1982. Liveright Publishing Corporation. New York. 2016 